\title{
Consumer Behaviour during Crises: Preliminary Research on How Coronavirus Has Manifested Consumer Panic Buying, Herd Mentality, Changing Discretionary Spending and the Role of the Media in Influencing Behaviour
}

\author{
Mary Loxton ${ }^{1}$, Robert Truskett ${ }^{1}$, Brigitte Scarf ${ }^{1}$, Laura Sindone ${ }^{1}$, George Baldry ${ }^{1}$ and \\ Yinong Zhao ${ }^{2, *}$ \\ 1 Discipline of International Business, University of Sydney, Sydney, NSW 2006, Australia; \\ mlox7301@uni.sydney.edu.au (M.L.); rtru7992@uni.sydney.edu.au (R.T.); bsca6477@uni.sydney.edu.au (B.S.); \\ 1sin9639@uni.sydney.edu.au (L.S.); gbal7274@uni.sydney.edu.au (G.B.) \\ 2 School of Economics, Fudan University, Shanghai 200433, China \\ * Correspondence: yinong.zhao@fudan.edu.cn
}

Received: 24 June 2020; Accepted: 19 July 2020; Published: 30 July 2020

\begin{abstract}
The novel coronavirus (COVID-19) pandemic spread globally from its outbreak in China in early 2020, negatively affecting economies and industries on a global scale. In line with historic crises and shock events including the 2002-04 SARS outbreak, the 2011 Christchurch earthquake and 2017 Hurricane Irma, COVID-19 has significantly impacted global economic conditions, causing significant economic downturns, company and industry failures, and increased unemployment. To understand how conditions created by the pandemic to date compare to the aforementioned shock events, we conducted a thorough literature review focusing on the presentation of panic buying and herd mentality behaviours, changes to discretionary consumer spending as defined by Maslow's Hierarchy of Needs, and the impact of global media on these behaviours. The methodology utilised to analyse panic buying, herd mentality and altered patterns of consumer discretionary spending (according to Maslow's theory) involved an analysis of consumer spending data, largely focused on Australian and American markets. Here, we analysed the volume and timing of consumer spending patterns; the volumes of spending on specific, highly-demanded consumer goods during the investigative period; and the distribution of spending on luxury and non-durable goods to identify the occurrence of these consumer behaviours. Moreover, to identify the presence of the media in influencing consumer behaviour we focused on web traffic to media sites, alongside keyword and phrase data mining. We conclude that, to date, consumer behaviour during the COVID-19 crisis appears to align with behaviours exhibited during historic shock events. We hope to contribute to the body of research on the early months of this pandemic before longer-term studies are available.
\end{abstract}

Keywords: coronavirus; COVID-19; consumer behaviour; panic buying; herd mentality; discretionary spending; media

\section{Introduction}

As the novel coronavirus spread globally from its outbreak in China, rates of infection and death caused by the virus began to spike significantly. As of 9 June 2020, confirmed global infections had reached 14,348,858, in addition to 603,691 confirmed deaths, revealing a fatality rate of approximately $4.21 \%$ (WHO 2020). Whilst a global pandemic might be expected to create market and economic volatility, as well as to create vastly intensified consumer uncertainty, these effects have been amplified 
during the current COVID-19 pandemic due to the inexistence of a vaccine (Li and De Clercq 2020; Liu et al. 2020). As uncertainty moves to alter consumption patterns, consumer decision making has been further exacerbated by periods of government-enforced self-isolation for returning travellers or individuals who might have been exposed to the virus, as well as broader city- or country-wide periods of social distancing where people were largely restricted to their homes. Hence, as regular consumer movement, capabilities and purchases were restricted, and as the fear of infection rose globally, consumer behaviour began to change in a capacity more than the typical geographic presentation of purchases, to affect the timing, breadth and volume of purchases.

Survival psychology acknowledges that individuals may undergo behavioural changes due to the occurrence of particular events, including natural disasters, healthcare crises and terrorist attacks (Forbes 2017). These behavioural changes might include negative occurrences of herd mentality, panic buying, changes to discretionary purchasing habits and investment decision making. Additionally, as there are no broadly researched modern pandemics outside of SARS, which was fairly localised in its presentation, research on COVID-19 will be formative for understanding and perhaps anticipating the future of shock and crisis research. This, and further future research, will become an important foundation for organisational and governmental preparedness for future shock events and pandemics.

Moreover, understanding the scope of the role of the media in influencing changed consumer patterns of behaviour and discretionary spending is increasingly important in our globalised world where technological advances have extended traditional domestic news stories to international audiences, such that the media has come to play a larger role in the promotion and intensification of consumer panic and anxiety. In line with contagion, defined as the spill-over of effects including fear and anxiety, caused by an extreme negative event in one location as it moves to affect others (Forbes 2012), we expect an increase in fear to alter rational consumer behaviour. Contagion effects are likely increased through increased international media communication and access. Hence, we anticipate that the COVID-19 crisis will not only see an increase in consumer fear but also the broader repercussions of this fear and uncertainty in spending decisions.

We first conduct a thorough literature review of various theories of consumer behaviour and behavioural models which have presented in a range of historic periods of panic, to understand how different events have caused consumer behaviour to change. Within our study, we examine include the SARS Outbreak, Christchurch earthquake and Hurricane Irma as periods where comparable consumer behaviour would likely have been exhibited. This process highlighted occurrences of panic buying, herd mentality and changing discretionary spending which we utilised as the basis of our analysis of consumer behaviour during the COVID-19 period. We then analyse data including spending patterns according to time, volume and range of purchases which might indicate panic buying, herd mentality and the intention behind consumer purchases (as defined by Maslow) to understand whether and how these same behaviours have been reproduced during the global pandemic. Finally, we make recommendations for how data from the coronavirus pandemic might be analysed further and over the longer term, particularly as consumer behaviour might prove to stabilise or alternatively continue to diverge from traditional patterns during periods of stability. As we conclude that consumer behaviours during the coronavirus pandemic do fall line with historical occurrences of shock events and crises, we hope to add value to academic study and Government planning for future shocks and crises, as well as to assist academics who might in future look to analyse behaviours over the entire duration of the pandemic.

\section{Theoretical Development}

\subsection{Panic Buying}

Panic buying is commonly recognised as behaviour exhibited by consumers where they purchase unusually large amounts or an unusually varied range of products in anticipation of, during, or after a disaster or perceived disaster, or in anticipation of a large price increase or upstream shortage 
(Yoon et al. 2017; Yuen et al. 2020). Panic buying often leads to large quantities of necessities and medical supplies being purchased from vendors, and vastly limiting or even eliminating availability such that individuals and vulnerable groups, including the elderly or poor, are prevented from accessing them as they would normally do (Besson 2020). As an indiscriminate consumer behaviour causing supply shortfalls and supply chain difficulties, and one exhibited both repeatedly and globally, the COVID-19 pandemic creates questions as to whether consumers can be better educated to avoid such behaviours in cases of inevitable future shocks and crises.

Research conducted by Yuen et al. (2020) in response to the coronavirus established four key factors causing panic buying: (1) perception, (2) fear of the unknown, (3) coping behaviour and (4) social psychology. They concluded that when consumers perceive the probability and consequences of contracting a disease to be high, they are motivated to undertake self-protective activities, including panic buying, to minimise perceived risk. Moreover, panic buying may be encouraged when consumers expect a product to become inaccessible and hence limit their personal freedoms by not possessing it; or alternatively when they can anticipate a sense of regret from not undertaking a certain behaviour or purchase, leading them to bring forward these intended purchases (Yoon et al. 2017). Fear of the unknown is reflected in panic buying behaviours as consumers channel their lack of knowledge about crises into behaviours perceived as comforting, providing security or that alleviate stress (Elmore 2017). This is reflected through studies showing that retail purchases have historically increased in preparation for impending disasters. Coping behaviours, including compensatory panic buying, are triggered when a source of discomfort cannot be brought under an individual's control, as they turn elsewhere to find control over or stress-relief from other domains. Finally, social psychological factors, including social influence and trust, might cause panic buying behaviours, as consumers react to the opinions and attitudes of larger groups, communities, and governments to guide their behaviours. When particular behaviours are undertaken or publicly reflected (e.g., in the media), consumers might experience a level of social distrust.

During times of uncertainty, consumer behaviour theories demonstrate how individuals attempt to gain a sense of control through product acquisition and panic buying (Ballantine 2013; Yuen et al. 2020). Whilst the outcome of the coronavirus and containment measures remain largely unknown, consumption of practical and regularly purchased products, such as cleaning products, is reasonable. However, as panic continues to grow, consumer reasoning is often outweighed by feelings of anxiety, rather than being made with reasonable cognitive conclusions (Loewenstein et al. 2001). Rational consumers assess the desirability and likelihood of an outcome and integrate this information to form a decision (Loewenstein et al. 2001); however, the "risk-as-feelings" theoretical perspective describes a trend towards irrational consumption during perceived instances of high risk, such as a crisis (Slovic et al. 2004). The stress and uncertainty experienced by consumers at the moment of decision making may lead to panic buying. Emotional reactions to stressful events often diverge from reasonable cognitive assessment, where the "risk-as-feelings" theory explains the excess consumption of particular goods which consumers might have judged as sensibly purchased at the time, including those which may be unreasonably hoarded. Hence, the risk-as-feelings theory can be used as a basis for the conceptualisation of panic buying behaviours, such that fear during a crisis or shock event leads consumers to skew their traditional patterns of spending towards purchases which might otherwise be undertaken at different times, at different volumes or perhaps not made at all.

Forbes (2017) study of the aftermath of the 2011 Christchurch earthquake examined immediate and short-term consumption patterns during a natural disaster crisis. Immediately after the event, i.e., within the first week, consumer purchases tended towards products which met basic physiological need for survival (i.e., water, non-perishable foods, baby care, heat and light), products providing communication services (i.e., telephones, radio batteries), and products for cleaning up and restoring normal life (i.e., paper towels, rubber gloves). This pattern of behaviour can have an exponential effect as the stockpiling of resources from panic buying can become transmissible (Thomas 2014). Fundamentally, sharp increases in demand for a product leads to widespread shortages, in turn creating 
additional panic buying and further increases in demand. Ballantine (2013) found that during the Christchurch earthquake in the short term, people had a higher propensity to visit smaller convenience stores and petrol stations as opposed to large supermarkets and shopping centres, due to the widespread fear that large buildings were at a higher risk of collapsing as a result of the earthquake. However, in the weeks following the disaster, as might be rationally expected, consumers sought the same products but in volumes suggesting they were stockpiling to prepare for future disaster events-particularly relevant considering the prevalence of aftershocks with the Christchurch earthquake. Hence, the anxiety caused by the initial shock, the earthquake, generated panic about the possibility of such events occurring again in the future, instigating future-oriented panic buying.

Elmore (2017) similarly reported that in the immediate lead-up to Hurricane Irma in the United States, whereas opposed to the Christchurch earthquake there was some warning, consumer spending in the West Palm Beach region fell $57.1 \%$ in total. This included an $84.9 \%$ fall in restaurant spending (considered largely discretionary spending) and reflects changing consumer behaviours during periods of shock or crisis. Moreover, spending on building supplies to shore up homes was recorded at $66.4 \%$ above the previous year, whilst spending at supermarkets rose $41 \%$ (Elmore 2017). Hence, as consumers anticipated the impact of the hurricane, their behaviours changed to tend towards panic buying to limit fear of the unknown and due to their perceptions of anticipated shortages, as outlined by Yuen et al. (2020). In fact, Kulemeka (2010) reported that in the United States, government officials have been known to encourage stockpiling prior to disasters to allow consumers to avoid reliance on charity or government aid should an event occur. Whilst this might be an unofficial policy, he notes that consumers tend to leave a portion of purchases to the last minute, creating further panic buying and price inflation when the event actually occurs (Kulemeka 2010). It is evident that the fundamental driver of panic buying behaviour, particularly in utilitarian goods, is a perceived lack of control and uncertainty surrounding a particular crisis. This, coupled by the transmissible aspect of panic buying, can create highly irrational consumer behaviour.

\subsection{Herd Mentality}

Herd mentality is defined as an alignment of thoughts and/or behaviours of individuals in a group, that emerges without purposeful coordination by a central authority or leading figure, and instead through local interactions among agents (Kameda and Hastie 2015). During periods of stress or shock, such as during the COVID-19 period, herd mentality manifests itself in several different key areas including stock prices, consumer purchase behaviours and collective societal anxiety. The key problem raised by herd mentality is that it creates a misallocation of assets, and hence pricing, in economies, as consumers rush to make particular purchases where supply cannot be quickly and sufficiently increased, or when volatility sweeps across stock markets to create funding and pricing issues (Dang and Lin 2016). Hence, understanding causes of herd mentality could help to inform policymakers and regulators about how to discourage this negative consumer behaviour.

Behavioural economics illustrates the effect of an information cascade, whereby consumers within a network are influenced by the behaviours and decisions of others (Easley and Kleinberg 2010). Furthermore, "scarcity heuristics" play further into the development of consumer fear during periods of shock, such that typically mundane items often see their value irrationally inflated through soaring demand (Cheung et al. 2015). Historical examples of this irrational behaviour are widespread, with Yoon et al. (2017) finding that upon Australian rice production falling 98\% during the 2008 drought, consumers in Vietnam, India and Hong Kong began to stockpile rice due to fears of insufficient future supply and exacerbating the issue further; and after Japan's Fukushima Plant nuclear leak in 2011, consumers globally began purchasing products which had been rumoured to prevent or reduce radiation poisoning, including iodine tablets in Bulgaria, salt in China, and red wine and seaweed in Russia. With these nonsensical consumer behaviours and the increasing scarcity of these products caused by an irrationally-led herd mentality combined with panic buying, economic issues in the affected economies are further worsened. 
Herd mentality also reflects Garrett Hardin's 1968 economic theory, Tragedy of the Commons, where individuals act independently according to their own self-interest, and usually behave contrary to the common good of all users by depleting a common shared resource through a collective action. Herd mentality encouraging consumers to unnecessarily stock up on consumer goods such as red wine, iodine tablets or salt demonstrates individuals satisfying their own self-interests rather than considering the good of the broader collective society. COVID-19 has threatened consumers' sense of security and created increased uncertainty in global markets, and as such, individuals' higher-than-normal consumption led by the rise of irrational herd mentalities to acquire a single resource at the expense of others, has led to severe overconsumption and depletion of the resource.

\subsection{Maslow's Hierarchy of Needs Model}

In examining instances of changing consumer behaviours in response to natural disasters or financial crises, it is fundamental to understand consumer decision-making processes. In applying Maslow's Hierarchy of Needs (1943), we analyse the satisfaction or utility behind particular wants and needs, and hence the ways that consumers are motivated to prioritise spending. This is particularly poignant for discretionary rather than non-discretionary spending which might be considered optional. Colloquially, Maslow's theory might be used here to classify purchases as "needs" versus "wants." A pyramidal hierarchy demonstrates the classification of consumer behaviours, and which classifications are considered most vital to human survival (Lester 2013). These five classifications, starting from the base of the pyramid as outlined by Lester (2013) include, (1) physiological necessities, (2) safety, consumer protection and wellbeing, (3) love and belonging, (4) self-esteem, and (5) self-actualisation or personal growth. In line with the hierarchy, consumers during crises tend to focus on satisfying basic physiological needs first, before moving onto higher levels and towards more luxury discretionary behaviours (Forbes 2017). Whilst Maslow's hierarchy is scaled according to the economic markets it is applied in, both advanced and emerging economies demonstrate similar shifts in consumer behaviour (Samli 2012). As such, Maslow's model provides a valuable platform for analysing consumer behaviour during periods of stress or anxiety, generated through emotions or more tangible stresses, such as a global pandemic.

During the 2008 Global Financial Crisis (GFC) and more generally during periods of economic downturn, disposable incomes are negatively impacted as wage growth falls and non-discretionary spending is prioritised. Hence, consumers re-evaluate behaviours during these periods to complement their economic environment, and the economy increases consumption of non-durable essential goods. Maslow's theory highlights the consumption of these non-durable goods as counter-cyclical, meaning it is positively correlated with negative Gross Domestic Product (GDP) output, and thus becomes a reflection of the business cycle (Black and Cusbert 2012). Maslow's higher order needs are typically deferred during periods of crisis, and thus in 2008, consumer spending on durable luxury goods, including machinery and equipment investments, were considerably more volatile than consumption of non-durable essentials (Black and Cusbert 2012). In correlation with GDP, Australia's average negative GDP growth during deep recessions from 1960 to 2010 measured at 2.6\%, and in line with Maslow's theory, durable luxury goods consumption averaged $-5.7 \%$ in year-on-year terms, whilst durable essential goods remained stable with a $0.6 \%$ positive increase (ABS 2012). As such, previous shock events have shown to alter consumer purchasing behaviour in line with Maslow's framework, where necessities are prioritised over goods considered discretionary.

Furthermore, in the decade following the GFC, a period of economic growth and strong business activity allowed individuals to have greater financial liquidity as panic in the environment fell. Once Maslow's lower hierarchical levels were fulfilled, consumer motivation shifted to satisfying Maslow's upper levels. In the five years immediately after the GFC, anticipated rising income per capita figures and strong global consumer spending drove revenue in several non-durable industries, including the Global Car and Automobile Sales industry, averaging 3.9\% annually (IBISWorld 2020). The United States, along with other developed nations, saw global growth and a shift in consumer motivations 
which supported annualised revenue growth of $4.2 \%$ in the five years to 2019 to USD $\$ 3.0$ trillion (IBISWorld 2020). Hence, Maslow's Hierarchy of Needs posits consumer consumption as reflective of the business cycle and prioritises essential goods during periods of crisis. We anticipate behaviour will prove similar in response to the current COVID-19 crisis.

\subsection{Role of the Media in Influencing Consumer Behaviour}

In the age of information, mass media plays a pivotal role in forming, remodelling and leading public opinion (Yang et al. 2019). This relationship becomes even more apparent during situations of crisis (Ghassabi and Zare-Farashbandi 2015), where the media has the capability to inform, dispel misinformation or insight hysteria through headlines. Indeed, Kilgo et al. (2019) report that whilst initial panic permeates organically from unfolding crises, the media contributes a disproportionate amount of anxiety by emphasising aspects of news stories which garner more attention, predominantly through provocation of fear. In analysis of the response to the H1N1 Swine flu of 2009 and Ebola outbreak of 2014-15, Pieri (2018) found this provocation to be especially true of pandemics in the form of media speculation and hysteria. While social media has become an increasingly influential source of news, national news coverage (and their media channels) remain the central framing mechanism of public and policy debates in regard to security and health emergencies (Dry and Leach 2010). Hence, developing an understanding of the way the media might affect or influence consumer decision making, whether this be on the scale of causing changed behaviours or simply informing consumer sentiment, is important for understanding motivations behind certain behaviours.

The most recent and relevant proxy for observing the impact of media coverage on consumer behaviour is through analysis of the 2014-15 Ebola crisis. In its initial stages, the disease was labelled as a "regional crisis," which saw no correlating consumer behavioural changes during the period. However, as media framing began to change towards reporting the virus as an "outbreak" and "pandemic" in September 2014, consumers began to panic about contagion in the West (Pieri 2018). Indeed, as the pandemic became increasingly portrayed as a "threat" to domestic security in the UK, more than 824 articles were written regarding Ebola between September 16 and October 16 (Pieri 2018). In contrast, only 225 articles were written on the topic when the WHO labelled the Ebola virus an emergency of international concern in August. The contrast in consumer behaviour was substantial.

Accordingly, as the first death occurred in the US, fearmongering and hysterical media coverage influenced several behavioural anomalies discussed earlier in the paper, such as panic buying and herd mentality. By October 2014, hazmat suits were selling for USD $\$ 1,300$ on Amazon and the US Centre for Disease Control (CDC) received a 135\% increase in phone calls enquiring about home remedies and concerns about products from Africa during the crisis (CDC 2016). While similar behaviours were seen during the SARS outbreak in 2003 when pharmacies in Baltimore were raided (McKeever 2020), the scale of consumer responses was comparatively pacified. The increased role of mass media across platforms has perhaps accentuated this panicked consumer behaviour. Given the behavioural response to Ebola (the most recent equivalent threat to global epidemiological safety), this paper questions whether similar behaviours have been exhibited following similar media provocation surrounding COVID-19. In assessing whether similar consumer behaviour has occurred, it may reveal insights which affirm the importance of media transparency during times of crisis. Understanding the effect media has during such periods may hence enable governments to predict and mitigate adverse effects of panic buying, avoid the significant "food crisis" that the United Nations (2014) feared could eventuate, and ensure a maintenance of normalcy during inevitable future events.

As a result of our theoretical review, our hypotheses surrounding the alteration to typical patterns of consumer behaviour due to the coronavirus pandemic are as below.

Hypothesis 1 (H1). Consumer behaviour during the COVID-19 period will follow panic-buying mentalities exhibited within previous crises, allowing some businesses to pivot their business models to take advantage of these behavioural changes. 
Hypothesis 2 (H2). Consumers will demonstrate herd mentality behaviours as a result of the COVID-19 pandemic, which have been targeted as business opportunities by some firms during the period.

Hypothesis 3 (H3). In line with Maslow's hierarchy of needs, consumer behaviours during the COVID-19 crisis will perhaps reflect the consumption of essential goods and prioritise Maslow's lower order needs.

Hypothesis 4 (H4). Media framing has played a significant role in influencing consumer sentiment during the COVID-19 crisis.

\section{Methodology}

\subsection{Panic Buying}

Panic buying of storable consumer goods is regularly seen during times of natural disasters or man-made crises. However, never has there been mass panic buying on an international scale as was experienced during the COVID-19 pandemic. Although research into panic buying has been minimal, the current pandemic provides a unique opportunity to study panic-buying behaviour due to the abundance of statistical data and variation of severity of its presentation. Government reactionary policy and its impact on consumer behaviour can also be analysed to a higher degree due to the variety of different policies implemented globally. This poses the question as to whether consumers within the coronavirus pandemic expressed similar buying mentalities of previous periods of panic and crises.

The COVID-19 pandemic has had a critical impact on consumer behaviours globally, as a rise in uncertainty has led to irregular and irrational consumer activity. To gain an understanding of whether the panic buying experienced within the COVID-19 outbreak follows the same mentalities of previous crises, a core understanding of the true impact COVID-19 has had on consumer behaviours must be established. To analyse changing consumer behaviours as they apply to panic buying, we first established the patterns of spending which could be used to identify panicked and irrational purchasing, i.e., our independent variables, whilst regular spending patterns exhibited outside times of crises was used as our comparative points of analysis, i.e., control variables. Once analysis of our independent variable against the control variables from the COVID-19 period was complete, we were able to compare these results to consumer behaviours exhibited during historical shocks to extrapolate whether our hypothesis regarding panic buying was satisfied or not.

\subsection{Herd Mentality}

In an event of scarce information and perceived imminent threat, people tend to follow the crowd rather than consider a more logical, individualised approach. In the context of purchasing behaviour during a crisis, this phenomenon perpetuates collective societal anxieties, where consumers are more likely to pay attention to the purchasing behaviours of their peers, than what is recommended by scientific or governing institutions (Brooks et al. 2012). Following empirical neuroeconomic consensus, the uncertain circumstances surrounding the current pandemic increase fear and panic among consumers, leaving them susceptible to herd mentality behaviours (Yuen et al. 2020). As previously noted, herd mentality manifests itself in several key areas: (1) collective societal anxiety, (2) consumer purchase behaviours, and (3) stock prices. These are highly interconnected, where collective societal anxieties change consumer purchase behaviours, altering business activity and impacting stock prices. Firms in recognising a change in consumer behaviours, will adapt their business models to capitalise upon this.

Establishing collective social anxiety is founded on a theoretical basis. Herd mentality and hoarding behaviours are driven by innate vulnerability factors, including intolerance of uncertainty (Mathes et al. 2017), and loss of control, whereby possession of a threatened consumer good restores a sense of security, comfort and preparedness (Frost and Hartl 1996). We can measure the effects through analysing major crises, where consumers experiencing similar distress and lack of foresight 
and control exhibited herd mentality. These include Hurricane Katrina (2003), where consumers exhibited hoarding behaviours, and the GFC (2007-2008). We compare the previous symptoms of herd mentality to the behaviours exhibited during the present crisis (i.e., our independent variable), to confirm our second hypothesis.

The COVID-19 pandemic is unique in that there have been limited pandemic experiences since the onset of behavioural finance and behavioural economic literature, thus we have limited empirical evidence for a causal relationship specific to this context. An analysis of this relationship is thus theoretical and predicated in consumer behaviour literature which notes similar herd-like behavioural patterns in the event of collective distress, such as natural disasters, and financial crises (Haghani et al. 2019). The existence of herd behaviours is supported by consumer behaviours which arise from herd mentality - panic buying (as explored in Hypothesis 1), hoarding, and stock price volatility.

Consumer purchasing behaviour in determining the presence of herd mentality forms our independent variable, therefore we find a proxy for this in spending on consumer goods. Here, spending data gained from ANZ and Commonwealth Bank covers three major consumer commodities: toilet paper, long-life food goods, and cleaning supplies. A marked increase in consumer spending from a basis point established in pre-crisis periods will confirm the existence of increased discretionary spending, and hoarding behaviours driven by herd mentality during the COVID-19 pandemic, and hence allow us to confirm or reject our hypothesis. Given the role of intolerance of distress and uncertainty in exacerbating hoarding behaviours (Mathes et al. 2017), in addition to previous exhibitions of hoarding during crises, hoarding behaviours are heavily linked to the herd mentality arising during the coronavirus pandemic.

\subsection{Maslow's Hierarchy of Needs}

Establishing the correlation between Maslow's Hierarchy of Needs and the economic business cycle demonstrates how consumer behaviours are expected to change during a crisis to prioritise spending on basic, essential goods. In analysing the GFC, a relevant proxy is established, as during this period of crisis, consumer behaviours followed Maslow's expectation of spending being shifted to the consumption of essential goods, and hence creating spending volatility for luxury items. This link was established by Black and Cusbert (2012), who examined consumer spending on durable goods (i.e., motor vehicles and household furnishings) which tend to be more cyclical than spending on non-durable goods (i.e., foods and transportation), as the consumption of luxury items can be readily postponed in times of economic weakness (Black and Cusbert 2012).

Maslow expects internal motivations to prioritise different basic, psychological and self-fulfilment needs depending on economic conditions and individual satisfaction. As discretionary income fell to 6\% of GDP and consumer confidence fell in late 2007 to 2008 (Freestone et al. 2011), "basic needs" were pursued first, as high-risk aversion and economic uncertainty motivated individuals to prioritise access to factors such as food, clothing and water. Consistent with Maslow's theory, Figure 1 demonstrates how consumer spending on durable goods fell more sharply than spending on non-durable goods and services during the GFC.

\begin{tabular}{|l|c|c|r|r|r|}
\hline & GDP & $\begin{array}{r}\text { Durable goods } \\
\text { consumption }\end{array}$ & $\begin{array}{r}\text { Non-durable goods } \\
\text { consumption }\end{array}$ & $\begin{array}{r}\text { Services } \\
\text { consumption }\end{array}$ & $\begin{array}{r}\text { Machinery \& } \\
\text { equipment investment }\end{array}$ \\
\hline Australia & -2.6 & -5.7 & 0.6 & 3.6 & -14.1 \\
\hline USA & -3.2 & -6.7 & -1.2 & 0.6 & -10.7 \\
\hline
\end{tabular}

Growth rates for each series calculated from GDP peak to trough in 1960-61, 1981-83, and 1990-91 for Australia and in 1974-75, 1981-82 and 2008-09 for the United States

Figure 1. Average Growth during Deep Recessions 1960-2010 (Source: Cycle, Black and Cusbert, RBA Durable Goods and the Business Study, 2012). 
Once individuals are satisfied and are behaving in line with rising economic activity, individual motivations will progress up through subsequent stages of Maslow's hierarchy of needs. In the decade following the GFC, consumer consumption shifted to prioritise higher order spending. During the current pandemic, consumer behaviour is in line with Maslow's motivation to satisfy basic needs first, exhibiting similar trends to those seen during the GFC. Hence, consumer spending data was analysed in the form of our independent variable to understand changing spending patterns during crises, and hence outline whether our hypothesis was satisfied by COVID-19 consumer behaviour.

\subsection{Role of the Media in Influencing Consumer Behaviour}

In analysing the media's role in influencing consumer sentiment, a series of quantitative and qualitative data were collated. In order to substantiate the hypothesis, an analysis was conducted of web traffic to mass media broadcasters during the period-variable data set 1 . This was sourced from web-analytics data collated by Pars.ly, the analytics provider for US mass media outlets such as the Wall Street Journal and NBC. Similar data to Australian websites was collected from self-reporting mechanisms from specific mass-media platforms. This data was assessed to substantiate the basis of the hypothesis: that mass media outlets were being paid significant attention during the early stages of the crisis. It is only following that analysis that can this paper seek to substantiate claims of influence on consumer sentiment - variable data set 2 . A causal link between the media and actualised consumer behaviour, as an extension of consumer sentiment, has been observed by several scholars including McQuail (1977), and Hirschman and Thompson (1997), who found that for nearly all concerns of public agenda citizens deal with a "second-hand reality," a reality structured by journalists' reports about these events and situations (McCombs 2018).

In assessing how these platforms framed the COVID-19 crisis and informed consumer behaviour, data was gathered and analysed through the secondary sourcing of peer-reviewed data. Primarily, this paper assessed media framing through use of keyword and phrase data mining. The data-mining platform Brandwatch Consumer research provided the quantitative analysis of inputted key phrases from which the results and discussions of this hypothesis were based. Hence, our independent variable was formed by the traffic experienced by news sites regarding the pandemic, which led to the acceptance or rejection of our final hypothesis.

\section{Results}

Through critical analysis of several crises, we find that the results do in fact suggest that the consumer behaviours experienced during the COVID-19 pandemic were highly comparable to those experienced during previous crises and shock events. As would be expected, the pandemic resulted in a steep decline in retail consumption. During March and April, the US saw a drop in total retail sales of $8.3 \%$ and $16.4 \%$ respectively (Trading Economics 2020a), with the obvious cause for much of this decline in spending being the closure of many stores as a result of government-enforced containment measures. We acknowledge that as these months occurred during the initial global rise in the pandemic, and although total retail spending fell, there were certainly specific segments which outperformed pre-pandemic months. Hence, it is difficult to attribute the decline in consumption directly to a lack of consumer confidence or the simple inability to physically purchase goods in the traditional store experience.

One major impact of panic buying during the period was price inflation due to supply shortages and opportunistic behaviour. Sudden increases in demand for particular products, driven by panic buying and a rise in herd mentality, resulted in households increasing their own individual demand for certain products, the most straightforward factor causing price inflation due to shortages. Opportunistic behaviours have presented in two key ways during the COVID-19 period. First, there are reports of individuals purchasing excessive volumes of non-discretionary household items which had seen large increases in demand, and reselling them at inflated prices in countries including Australia and the US (Le Grand 2020; Wray 2020). Moreover, price inflation was exacerbated by organisations and suppliers, 
who were reported to have increased prices of both raw materials and final goods to capitalise on the pandemic. Medical supplies saw some of the largest price surges due to their obvious need in fighting coronavirus, where Le Grand (2020) reported an increase in medical gown prices from USD $\$ 1.65$ to \$5.50, and boxes of alcohol swabs from USD\$50 to 99.

Limits were put in place by retail suppliers in an attempt to reduce price inflation and limit panic-buying behaviours surrounding "essential" items. For example, Australian supermarket giants Woolworths and Coles set limits on items including toilet paper, mince meat, eggs, milk, pasta, flour, long-life milk and liquid soap (Swain 2020). However, often these policies often had the opposite effect, as the sudden portrayal of supply shortages increased public fear and resulted in highly irrational herd behaviour. This depiction of panic and limited supplies could perhaps be concluded to have been intensified through portrayal in the media. Interestingly however, not all irregular consumer patterns seen in times of crises can be described as irrational. The Hurricane Irma crisis saw demand for hardware products aimed at preventing hurricane damage significantly increased. Elmore (2017) reported that building supply sales increased $66.7 \%$ in the West Palm Beach region in the immediate leadup to the event. Although overall consumption decreased considerably during both Hurricane Irma and the current pandemic (Trading Economics 2020b), both crises saw a large surge in demand for non-discretionary goods, where a surge in demand for medical equipment during the COVID-19 pandemic has stark similarities to the increase in demand for building supplies during Hurricane Irma. Interestingly, the mass purchase of these necessary, non-discretionary goods in both crises is an example of rational panic buying, where it is logical for consumers to purchase more of these goods than what would normally be bought; in stark contrast to the irrational mass hoarding of goods in the current crisis.

Consumer behaviour literature and neuroeconomic analysis highlight that social context is a major driver of consumer decisions (Jeffrey and Putman 2013; Brooks et al. 2012; Zhang et al. 2014). When presented with a situation in which foresight is limited and information is ambiguous, consumers panic and look to their peers for behavioural guidance (Brooks et al. 2012). Our results are consistent with previous crises, where herd mentality is a consequence of social context, fear of scarcity, and loss of control over one's surroundings, inducing hoarding and preparation activities as a coping mechanism.

Increased hoarding activities and the exhibition of herd mentality behaviours are consistent with previous crises, as at the first signs of disaster, it is common to see the hoarding of goods considered important, such as toilet paper (Kaigo 2012). Increased consumer purchases of specific consumer goods, our independent variable for Hypothesis 2, which causes increased temporary product shortages likely induced perceptions of product scarcity surrounding consumer goods, contributing to the onset of herd mentality (Hypothesis 3). Psychological reactance theory notes that product scarcity can be experienced by consumers as a loss of control, thus increasing its perceived necessity (Clee and Wicklund 1980). In this context, possessions provide a sense of security (Frost and Hartl 1996). A study by consulting firm NC Solutions, found that US toilet paper purchases rose 51\% between February 24 and March 10, 2020; however, following lockdown announcements by various states, sales rose $845 \%$ between 11-12 March (NC Solutions 2020a). On 12 March, US consumers increased spending on household consumer packaged goods by 55\%, nearly doubling their purchases on the week prior (NC Solutions 2020b). Hoarding activities increased from 11-21 March, where average household spending increased by 35\% compared to pre-COVID-19 purchase levels (NC Solutions 2020c). In Australia, this was reflected in consumer spending on groceries and toiletries; where in the week ending 20 March 2020, spending had increased 80\% from the same period in the year before (Timbrell and Plank 2020) (see Figure 2). 


\section{Spending in Selected Economies*}

Nominal spending, December $2007=100$

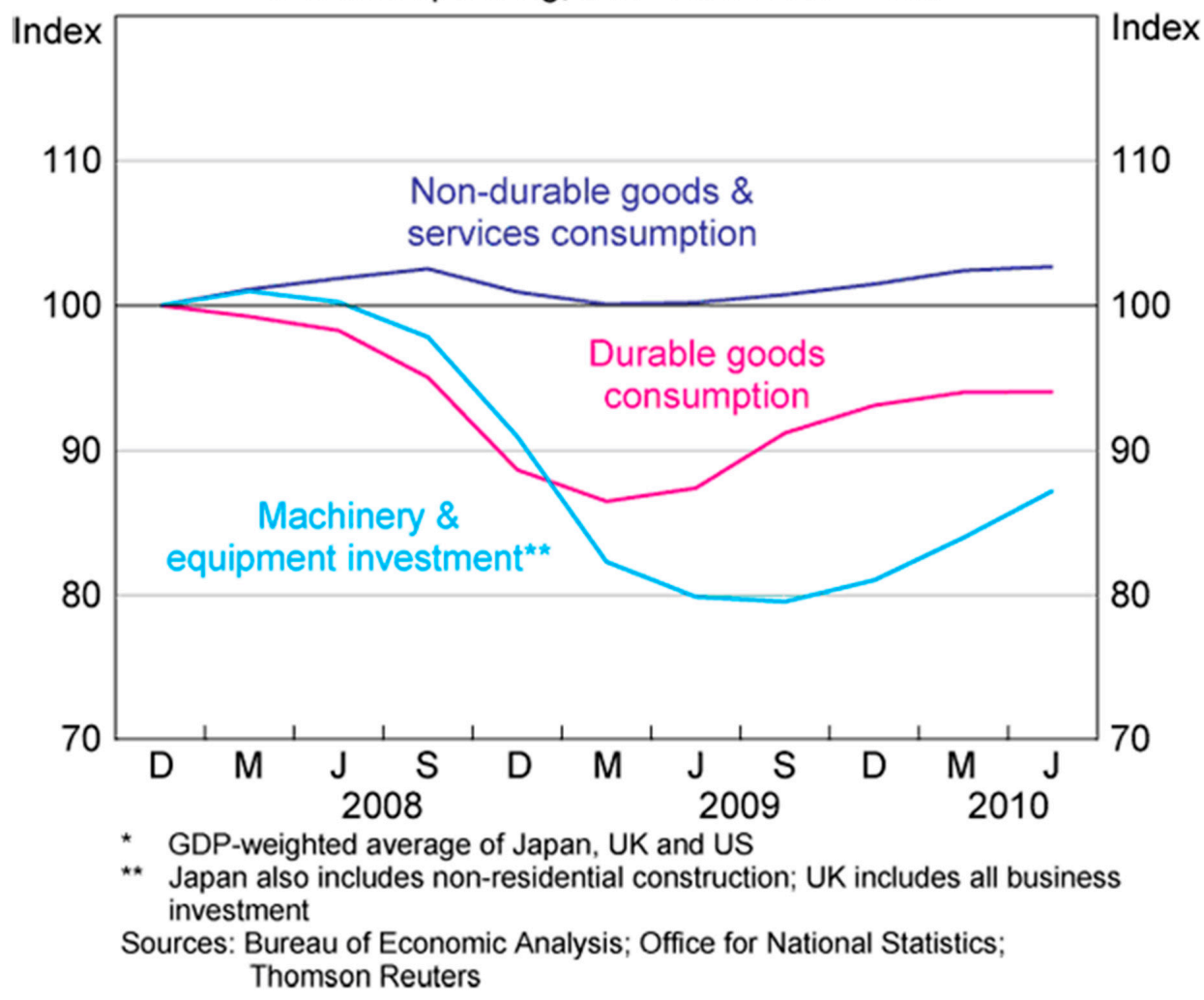

Figure 2. Spending in Selected Economies November 2018-February 2010 (Source: Cycle, Black and Cusbert, RBA Durable Goods and the Business Study, 2012).

Furthermore, our results indicate that businesses may leverage herd mentality behaviours as business opportunities. Over 130 Australian companies volunteered their resources or production facilities to produce personal protective equipment (PPE) including medical-grade masks and gowns (Knaus 2020), and globally with firms including Gap, H\&M, Nike, Prada and Zara doing the same (Accardi 2020).

In line with previous periods of crisis, consumer behaviour during the COVID-19 period has demonstrated a shift in consumption of basic needs and non-durable items, prioritising the base layer of Maslow's Hierarchy of Needs. In May 2020, Australia's unemployment rate spiked to $6.2 \%$ as 600,000 jobs were lost, and the economy shifted towards a recession (Murphy 2020). ANZ reported a fall in consumer sentiment of 27.8\% in March 2020, a level 17\% below the trough reached in October 2008 during the GFC (Wright 2020). As uncertainty rises, individual wage growth falls and spending is prioritised towards basic needs. During this period, non-durable goods, as an indicator of a basic household priority, saw essential stores such Woolworths increase revenue by $10.7 \%$ to 16.5 billion in the March 2020 quarter (Anderson 2020). Over the same period, the Australian Food Business, including all supermarkets, saw total sales increase by $11.3 \%$ to USD 11.2 billion, peaking in the final week of March with growth over $40 \%$ year on year (Anderson 2020). This shift in consumer behaviour is in line with previous periods of economic crisis and demonstrates how consumers move to satisfy their basic needs first. Comparatively, Amazon reported "durable" goods during this same period experienced the greatest decline, as online sales luggage $(-77 \%)$, briefcases $(-77 \%)$ and cameras $(-64 \%)$ all plummeting (Jones 2020). Here, we see the trade-off between durable and non-durable (and perhaps luxury) goods and how Maslow's Hierarchy of Needs predicts this consumer behaviour during a period of economic downturn. 
The second tier of Maslow's hierarchy, safety needs, is applied to the COVID-19 period as outlining an individual's sense of security and protection against the outbreak of the virus (Siddiqui 2020). It includes an individuals' need for goods which might increase their feeling of security, including hand sanitisers, masks, disinfectant and other sanitary items. Consumer consumption has shifted to reflect this need, as with consumption of medical necessities including disposable gloves increasing by $670 \%$ in March 2020 in a year on year basis (Jones 2020). Additional supplies including cough medicine increased by $535 \%$, toilet paper $190 \%$, vitamins $166 \%$ and pain relievers $99 \%$ (Russell 2020). The commonality between all products is the ability or perception that they might safeguard consumers against the virus. As expected, consumers have shifted consumption to fulfil more essential and practical needs at the bottom of Maslow's pyramid before achieving self-fulfilment needs.

The analysis of web-analytics and traffic surrounding consumer access to media websites suggests that mass-media attracted significant attention during the beginning of the COVID-19 pandemic. Between February and March 2020, the 13 major US new outlets increased web-traffic by 30\%, whilst Australian news outlets over the same period increased by an average of $54 \%$. These figures are significant, and it validates the increased informative power that mass media outlets have during periods of crisis, a finding affirmed by McQuail (1977), and Hirschman and Thompson (1997). Moreover, analysis of key-phrase data affirmed that media framing was highly correlated and thus presumed to have a degree of influence toward subsequent consumer mentality. Our analysis found that the words "out-of-stock" observed 137,000 mentions on mass-media sites globally, whilst the term "stockpiling" observed 232,000 mentions. Both aforementioned peaks occurred prior to the observed consumer behaviour and fear-sentiment peaking, indicating that the media coverage had a perpetuating influence on behaviour. The implications of these results are further extrapolated in the discussion.

\section{Discussion}

\subsection{Discussion on Panic Buying}

In line with our review of consumer behaviour during previous shock events, COVID-19 has seen similar panic buying behaviours emerge globally. As consumer fear and anxiety increased worldwide, consumers began to establish categories of products which they considered essential. This included, but not limited to tinned foods, minced meat, dried goods (e.g., pasta, rice), baking supplies (e.g., flour, sugar), eggs, toilet paper, baby nappies and formula, hand sanitiser, facial masks and gloves. As government-enforced shutdowns continued, shortages of particular goods related to the lack of consumer freedoms or reduced leisure opportunities emerged, including home gym equipment, bikes, hair clippers, office equipment and gaming consoles (Raymond 2020). Accompanied with the unique containment measures and social restrictions arising from COVID-19, consumer behaviours were greatly impacted by their respective networks.

With volumes and timing of consumer purchases of these products specified as our independent variable for the identification of panic buying during the COVID-19 period, the increases reported identify this phenomenon as occurring. Following similar trends of previous panic buying scenarios, the US saw a $32.5 \%$ increase year-on-year in grocery spending in the month of March and a $12.8 \%$ reduction in April (Trading Economics 2020a). This suggests that panic buying is either a relatively short-term occurrence and/or that over-spending in March meant consumers had sufficient supplies to last them through April. In March 2020, Statista found that toilet paper sales exceeded estimates by $140 \%$ in Italy, $98 \%$ in Australia, $82 \%$ in Spain and $80 \%$ in the UK (Buchholz 2020). With clear evidence of irregular consumption patterns in regard to the volumes and timing of consumer purchases during the COVID-19 pandemic, similarities must be established between present circumstances and previous periods of crisis.

A recent study conducted by the University of New South Wales (UNSW) business school created a panic index to model the effects virus transmission and reactionary policy has on panic responses. The study more generally indicated the greater the fear associated with a crisis the greater 
the panic buying that occurs (Norman 2020). However, the model also indicated that panic buying was not impacted by increases in the number of infected people as much as it was by legislation and restrictions put in place by governments. Panic buying was experienced almost entirely in the short term, with increased consumption levels associated with the spike in panic buying which began to stabilise within 10 days of an announcement (Keane and Neal 2020). Hence, the announcement of internal restrictions caused the largest, albeit fairly short-term, impact on consumption patterns within Australia and globally. Therefore, with these patterns in consumer behaviour established, we confirm that our hypothesis has been satisfied by the pandemic, and hence that consumers do exhibit panic buying behaviours during periods of crisis or shock.

\subsection{Discussion on Herd Mentality}

Consumer neuroeconomic analysis highlights that social context is a major driver of consumer decision making (Jeffrey and Putman 2013). When presented with a situation in which foresight is limited and information is ambiguous, consumers panic and look to their peers for behavioural guidance (Brooks et al. 2012). The widely cited Asch (1955) conformity experiments reveal a participant doubts their own judgement when faced with alternative groupthink. In addition, further studies found people to experience increased activity in the amygdala and insula, the fear centres of the brain, when faced with uncertainty in a group context (Brooks et al. 2012). In 2012, Hurricane Sandy hit the US, with devastating effects despite mass warnings. A survey prior to the storm revealed residents had acute awareness of storm severity $(80 \%)$; however, preparations for the storm were comparatively limited: just $20 \%$ of residents had a disaster plan (Myer et al. 2014). Excessive optimism within the population caused many people to underestimate the severity of the storm, however neglected to consider the effect on themselves (Myer et al. 2014). Herd thinking compounded this issue, such that if most community members were not making preparations, a resident felt reduced pressure to do so (Jeffrey and Putman 2013). We see the same cognitive bias take the opposite effect in the case of coronavirus: consumers became aware that the majority group were making preparations for long-term lockdown, and thus were driven to generate similar conclusions of necessity and engage in the same hoarding behaviours.

Herd mentality driving the hoarding of food, toilet paper and cleaning materials is reflective of the Tragedy of the Commons theory, whereby consumers engage in panic purchases and hoarding behaviour out of self-interest and opportunism, despite the general understanding that these decisions undermine collective interest (Hardin 1968; Rapoport and Chammah 1965). A perceived lack of control over an event is positively associated with level of stress (Kennett-Hensel et al. 2012). An ambiguous and intense situation, such as the unprecedented COVID-19 restrictions, can induce feelings of distress and helplessness (Kennett-Hensel et al. 2012). Thus, consumers are more likely to participate in activities that offer a sense of security and comfort, regardless of long-term or broader societal implications (Rapoport and Chammah 1965). Given increased purchasing behaviours were normalised by the coronavirus epidemic, consumers may experience a sense of comfort in both the possession of products perceived as important (Frost and Hartl 1996), and the socially encouraged nature of such behaviours (Jeffrey and Putman 2013).

Scarcity heuristics exacerbate the development of consumer unease and fear during periods of crisis; so typically, mundane items see their value irrationally inflated and demand soar (Cheung et al. 2015). Hence, herd mentality is perpetuated amongst typically rational consumers. Such perceptions of scarcity were likely exacerbated by media depictions of panic purchasing, as increased hoard mentality behaviours were correlated with media coverage, or government preparation announcements. In Japan, rumours in early February that an economic standstill in China would lead to shortages in toilet paper and other consumer products, as defined by Hypothesis 2 as indicating the occurrence of herd mentality, induced significantly increased consumption levels driven by herd mentality (Johnston 2020).

As noted in our results, firms seeking to take advantage of herd mentality during the COVID-19 period may have changed or extended their business models. These primarily assist with the production 
and distribution of products deemed scarce in supply or in high demand due to the panic purchasing of products. For example, during the COVID-19 period, we have seen various manufacturers move into the production of hand sanitiser. These included beauty and grooming manufacturers LVMH, Coty and Procter and Gamble, and breweries Carlton United Breweries, Bacardi and Bundaberg Rum (Smiedt 2020; Smith 2020). Hence, as herd mentality behaviours caused anxiety about and the realisation of consumer goods globally, manufacturers were able to pivot to accommodate shifting consumer demands, and profit from doing so. Examining these results, our hypothesis regarding consumer exhibition of herd mentality behaviours via their purchase of essential consumer goods during crises has been satisfied by the COVID-19 pandemic.

\subsection{Discussion on Maslow's Hierarchy of Needs}

COVID-19 has manifested itself globally as both a health and economic pandemic, striking individuals' emotional reactions from the base of Maslow's hierarchy of needs pyramid. Basic needs are prioritised during times of distress or anxiety, and consumers shift their behaviour to focus on "panic buying" of non-durable goods which aid in survival, including food, water and medication as the most basic examples. The hoarding of such non-durable items highlights the perceived unpredictability of future events and the anticipation of not being able to acquire those basic consumer goods in the future. At the peak of the COVID-19 outbreak, individuals were placed under strict containment measures; however, consumers were willing to leave homes to purchase essential goods at the expense of their health. This demonstrates how consumers are motivated to satisfy Maslow's lower-order needs by disregarding potentially negative economic or health outcomes. Consumers forego their motivation for higher order satisfaction, as an environment of consumer panic priorities these basic needs.

Moreover, Maslow's hierarchy suggests that each human need is a prerequisite of the subsequent need type, and therefore one cannot begin to fulfil third-, fourth- and fifth-order needs without satisfying the most basic needs first (McLeod 2007). As consumers focus on achieving these fundamental priorities, ensuring access to food, shelter, water and safety products against the virus, they are hence not so motivated to achieve higher order desires (Maslow 1954). Therefore, during the current crisis, consumers will continue to satisfy lower order needs until they are confident the threat of coronavirus has subsided. As containment measures continued to be eased and social distancing measures relaxed, it is expected consumers will begin to shift spending again to pre-COVID-19 priorities, which might include spending on durable goods, and can focus on achieving higher order self-actualisation. Hence, to date, COVID-19 consumer behaviours appear to be following the example of historic shocks and crises with consumers re-defining priorities for spending according to disposable income and needs, satisfying Hypothesis 3.

\subsection{Discussion on the Influence of the Media}

Assessing the media's role or indirect influence during the COVID-19 period is a complex task, as there were several environmental factors which influenced the media's influence on consumers. Firstly, in the US and UK, there has been a lack of clarity and reliability in the information being conferred by typically trusted sources of the White House and Downing Street (which is traditionally reported on). Secondly, news media has been categorically dismantled in terms of structure and trust garnered over the past 5 years (Natividad 2020). As a result, mass media has faced the pandemic with unreliable information, an inherent lack of trust from consumers and with severely understaffed workforces in many cases. Even in the face of these headwinds, factors such as working from home and increased levels of anxiety augmented the historically observed reliance of media in times of uncertainty and crisis (Ball-Rokeach and DeFleur 1976). Indeed, between February and March 2020, online traffic of the US's 13 major news outlets increased by 30\% (Parse.ly 2020). Similar results were observed domestically in Australia, with the Guardian Australia observing an audience increase of $104 \%$ during March 2020, the ABC recording a 40\% increase and The Australian recording a doubling of readership 
(Vitorovich 2020). Consumers, it was therefore assumed, were directing their attention to major news outlets during the period, which might have influenced their sentiment and hence their behaviour.

The question then became how these outlets were framing the crises and how any framing has corresponded with consumer sentiment and behaviour. On 30 January 2020, WHO (2020) designated the COVID-2019 outbreak a "public health emergency of international concern." The media reception to this announcement was of speculation and sensationalism, a direct reflection of the ambiguous responses received by trusted institutions. For example, WHO did not declare COVID-19 as a pandemic until 11 March, and America's CDC did not inform people to stop gathering in groups until $15 \mathrm{March}$. As noted by various scholars, when there is an absence of crucial information, either because it is ineffectively communicated or unknown, ambiguity can lead to a heightened appraisal of threat (Garfin et al. 2020). This was observed in the COVID-19 media response, as cases began to occur domestically. Media outlets identified the virus as a "killer virus" and "deadly disease" (Mannix 2020), which considering the mortality rate is sensationalist and fear inducing. By mid-February, the media consensus of threat became undisputed, and immediately the media's framing shifted to social implications including issues such as stockpiling and hoarding of staple goods. The changes to consumer sentiment as influenced by the media, which perhaps then influenced behavioural trends became notably more self-perpetuating as news outlets continued to report the behaviour. This confirmation bias of anxieties was studied by Reid (2020) who found that the words "out of stock" had a total mentions of 137,000 followed by a store name in just one week of Feb-March 2020 across the US, UK and Australia by major news outlets, visualised in Figure 3.

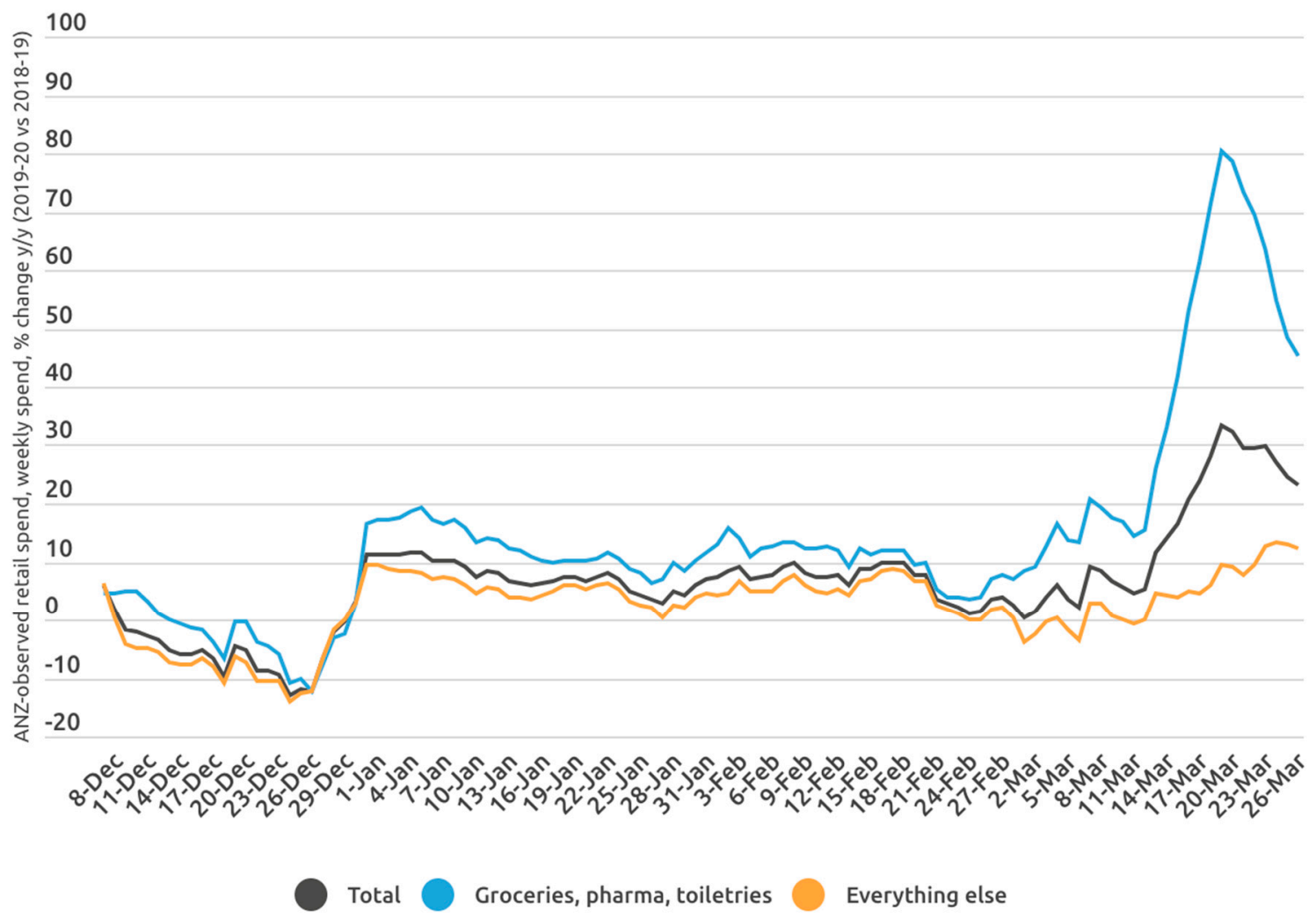

Figure 3. Consumer Spending on Groceries and Toiletries (Source: Timbrell and Plank, Bluenote ANZ, 2020).

Importantly, Reid (2020) also noted that the number of articles mentioning coronavirus "stockpiling" peaked prior to the observation of the behavioural peak across the three markets (US, UK, Australia), in Figure 4. This lag is indicative of the influential role media had on abnormal behaviour during the period, a phenomenon sighted by the American Psychological Association who assert that increased 
distress and anxiety is promulgated as a result of media exposure (Garfin et al. 2020). The lagged increased engagement in the articles is evidence of this relationship and can be seen below. Similarly, Figure 5 illustrates the number of articles published mentioning "stockpiling" during the coronavirus pandemic, showing a peak in early March as confirmed cases rose significantly. Hence, an analysis of these graphs illustrates that it is clear that the hypothesis that the media played a significant role in consumer behaviour during the COVID-19 outbreak thus far is affirmed.

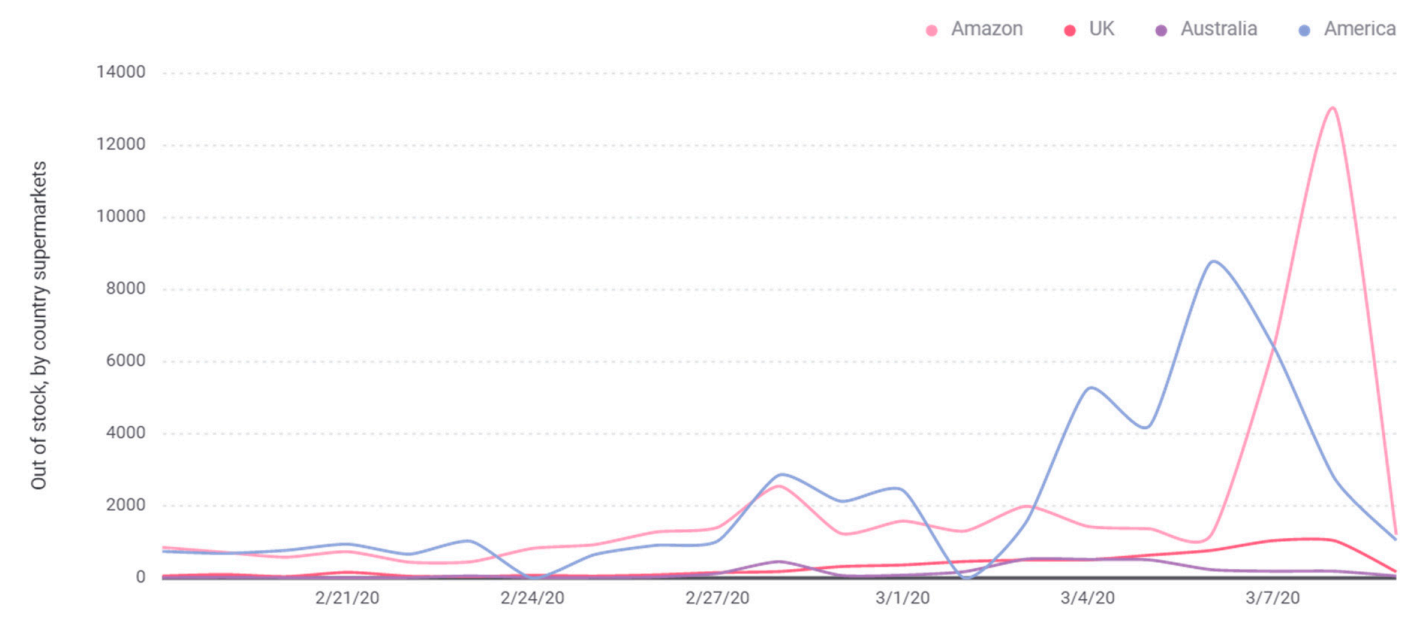

Figure 4. Mentions of "Out of Stock" Alongside a Store Name (Source: Brandwatch Consumer Research, 2020).

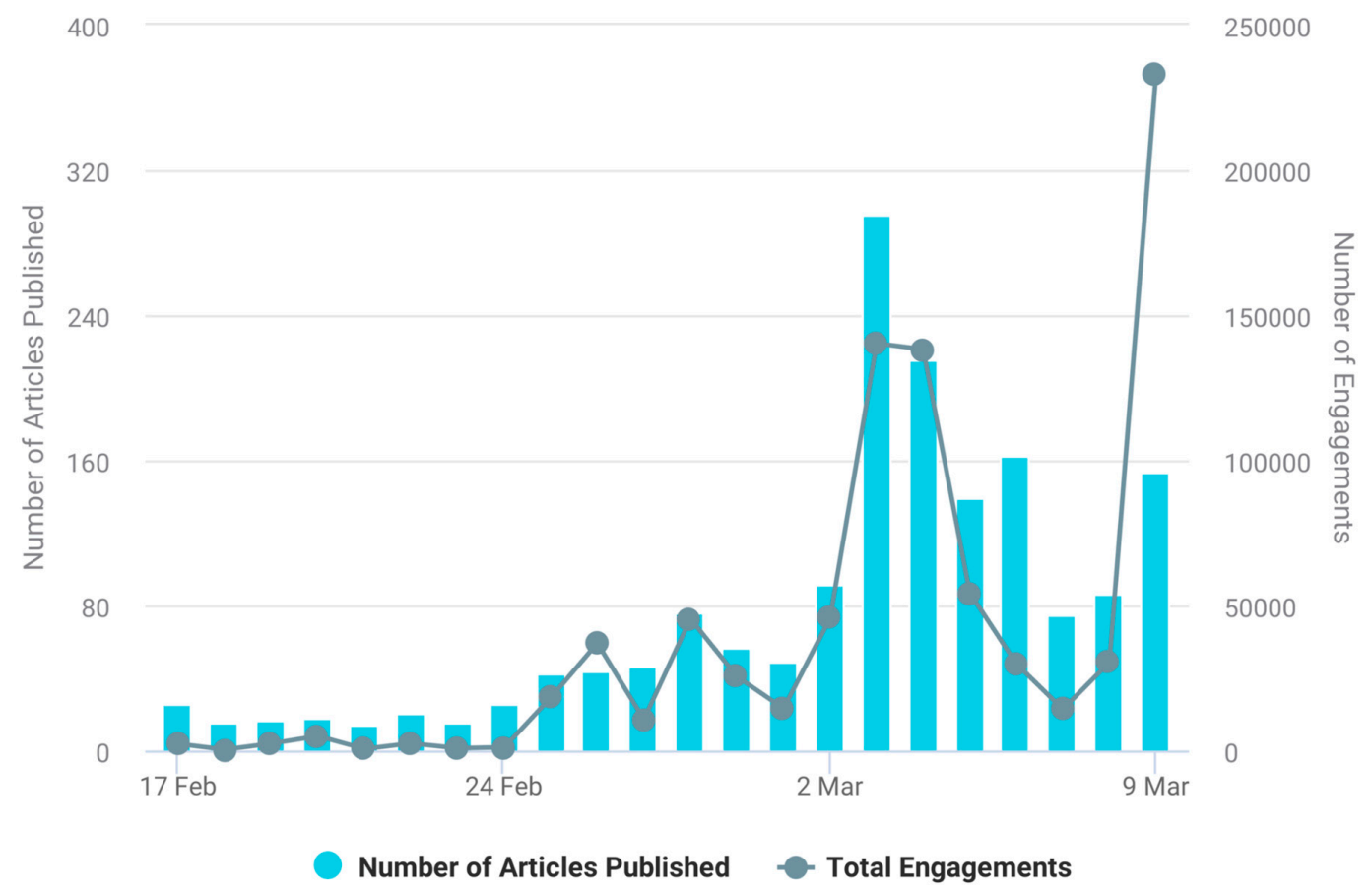

Figure 5. Number of Articles Published Mentioning Coronavirus "Stockpiling" (Source: Brandwatch Consumer Research, 2020).

\subsection{Limitations and Future Research Directive}

Our paper provides a preliminary review of long-term consumer behaviours which are raised during periods of crisis and shock, including panic buying, herd mentality and the prioritisation of purchasing decisions according to Maslow's Hierarchy of needs, and attempts to conclude whether these are applicable to the current coronavirus pandemic. Whilst we have done this, and conclude that 
all three have been illustrated in the current context, there is further research to be done to understand any causality between the three factors as there likely would be. We acknowledge that the existence of panic buying and herd mentality is likely to display causality between the two factors, and furthermore, the role of the media in directly influencing changing consumer behaviours in relation to panic buying and herd mentality may be established. Hence, we acknowledge that the role of this study is to provide a preliminary understanding of consumer behaviours and how they relate to the current coronavirus pandemic.

Further areas of study might also include how these behaviours, panic buying, herd mentality and the changing consumer discretionary spending patterns, as outlined by Maslow, could be further analysed to understand how they might impact variables including stock prices and trading volumes. As has been clearly demonstrated during the current crisis, and has been similarly illustrated during previous crises including the GFC and the bombing of the World Trade Centre in 2001, capital markets are highly reactive, and hence the same levels of reaction might be expected to arise in the current context. Moreover, future research directives could involve understanding whether capital markets respond differently to economic, pandemic and terrorist events. Using benchmark proxies from previous global shocks such as the GFC, insights could be garnered from sentiment proxies to understand investor responses to unexpected economic shocks. These findings would arm governments and policy makers with knowledge to assist in mitigating downside risks for investors and the broader economy in the future.

\section{Conclusions}

As the coronavirus pandemic may be categorised as a broader healthcare crisis than has been experienced in recent history, for example as experienced during the SARS outbreak, it is not possible to immediately anticipate that all consumer behaviours typically demonstrated during more common shocks or crises, such a natural disasters, to apply here. A further complication of analysing consumer behaviour during the COVID-19 period is the international scope of the pandemic, as opposed to the more typical, localised geographic regions, making this pandemic truly unique in the scope of historic crises. Moreover, the current inexistence of a vaccine means that until one is developed and administered on a widespread basis, uncertainty and fear will continue to manifest in unstable and reactive spending patterns, investment decision-making and stock prices. Our study concludes that, to date, consumer behaviour in the form of panic buying, herd mentality and discretionary spending as anticipated by Maslow's Hierarchy of Needs appears to align with behaviours exhibited during shocks and crises of the past.

Author Contributions: Conceptualization and methodology, M.L.; writing-original draft preparation, M.L.; writing—submitted paper, M.L., R.T., B.S., L.S. and G.B.; writing—post-submission editing, M.L.; funding acquisition, Y.Z. All authors have read and agreed to the published version of the manuscript.

Funding: This research received no external funding.

Acknowledgments: The authors would like to thank and acknowledge the assistance and support of Xue-Feng Shao for his supervision and feedback which have contributed to this paper.

Conflicts of Interest: The authors declare no conflict of interest.

\section{References}

Accardi, Nicolette. 2020. These Retailers Are Using Their Manufacturing Facilities to Make Masks and Hospital Equipment. Available online: https://www.nj.com/business/2020/03/these-retailers-are-using-theirmanufacturing-facilities-to-make-masks-and-equipment.html (accessed on 2 June 2020).

Anderson, Timothy. 2020. Woolworths Group Ltd.: March Quarter 2020 Sales Report. Australian Stock Report. Available online: https://www.australianstockreport.com.au/insights/woolworths-group-ltd-march-quarter2020-sales-report (accessed on 10 June 2020).

Asch, Solomon. 1955. Opinions and social pressure. Scientific American 193: 31-35. [CrossRef] 
Ballantine, Paul W. 2013. Changes in retail shopping behaviour in the aftermath of an earthquake. The International Review of Retail, Distribution and Consumer Research 1: 28-42. [CrossRef]

Ball-Rokeach, Sandra, and Melvin DeFleur. 1976. A dependency model of mass-media effects. Communication Research 3: 3-21. [CrossRef]

Besson, Emilie K. 2020. COVID-19 (Coronavirus): Panic Buying and Its Impact on Global Health Supply Chains. World Bank. Available online: https://blogs.worldbank.org/health/covid-19-coronavirus-panic-buying-andits-impact-global-health-supply-chains (accessed on 14 June 2020).

Black, Susan, and Tom Cusbert. 2012. Durable Goods and the Business Cycle. Reserve Bank of Australia. Available online: http://www.rba.gov.au/publications/bulletin/2010/sep/pdf/bu-0910-2.pdf (accessed on 29 July 2020).

Brooks, Andrew, Monica Capra, and Gregory Berns. 2012. Neural insensitivity to upticks in value is associated with the disposition effect. NeuroImage 59: 4086-93. [CrossRef] [PubMed]

Buchholz, Katharina. 2020. Toilet Paper Producers Roll'ing in the Dough. Available online: https://www.statista. com/chart/21327/rise-in-revenue-toilet-paper-selected-countries/ (accessed on 17 June 2020).

CDC. 2016. Lessons of Risk Communication and Health Promotion-West Africa and United States. Atlanta: Centres for Disease Control and Prevention.

Cheung, Tracy, Floor Kroese, Bob Fennis, and Denise De Ridder. 2015. Put a limit on it: The protective effects of scarcity heuristics when self-control is low. Health Psychology Open 2: 1-11. [CrossRef]

Clee, Mona, and Robert Wicklund. 1980. Consumer behaviour and psychological reactance. Journal of Consumer Research 6: 389-405. [CrossRef]

Dang, Ha, and Mi Lin. 2016. Herd mentality in the stock market: On the role of idiosyncratic participants with heterogeneous information. International Review of Financial Analysis 48: 247-60. [CrossRef]

Dry, Sarah, and Melissa Leach. 2010. Epidemics: Science, Governance and Social Justice. London: Routledge.

Easley, David, and Jon Kleinberg. 2010. Networks, Crowds, and Markets: Reasoning about a Highly Connected World. Cambridge: Cambridge International Press.

Elmore, Charles. 2017. Irma: Frenzied buying in Palm Beach, St. Lucie regions led state. The Palm Beach Post. Available online: https://www.palmbeachpost.com/business/data-firm-tracked-how-hurricane-irma-storesales-boomed-went-bust/LIDVXIL3qlqJGLlaosfSiL/ (accessed on 30 June 2020).

Forbes, Kristin. 2012. The "Big C": Identifying and mitigating contagion. NBER Working Paper 18465. MIT Sloan School Working Paper 1-42. [CrossRef]

Forbes, Sharon L. 2017. Post-disaster consumption: analysis from the 2011 Christchurch earthquake. The International Review of Retail, Distribution and Consumer Research 27: 28-42. [CrossRef]

Freestone, Owen, Danial Gaudry, Anthony Obeyesekere, and Matthew Sedgwick. 2011. The Rise in Household Saving and Its Implication for the Australian Economy. Economic Round-up 61-79. Available online: https://www.nber.org/papers/w18465 (accessed on 29 July 2020).

Frost, Randy O., and Tobias Hartl. 1996. A cognitive-behavioural model of compulsive hoarding. Behaviour Research and Therapy 34: 341-50. [CrossRef]

Garfin, Dana, Roxanne Silver, and Alison Holdman. 2020. The Novel Coronavirus Outbreak: Amplification of Public Health Consequences by Media Exposure. Worcester: American Psychological Association.

Ghassabi, Fateme, and Firoozeh Zare-Farashbandi. 2015. The role of media in crisis management: A case study of Azerbaijan earthquake. International Journal of Health System E Disaster Management 3: 95-102.

Haghani, Milani, Emiliano Cristiani, Nikolai W.F. Bode, Maik Boltes, and Alessandro Corbetta. 2019. Panic, irrationality, and herding: Three ambiguous terms in crowd dynamics research. Journal of Advanced Transportation 2019: 1-58. [CrossRef]

Hardin, Garrett. 1968. The tragedy of the commons. Science 162: 1243-48.

Hirschman, Elizabeth, and Craig Thompson. 1997. Why media matter: Toward a richer understanding of consumers' relationships with advertising and mass media. Journal of Advertising 26: 43-60. [CrossRef]

IBISWorld. 2020. Global Car \& Automobile Manufacturing Industry-Market Research Report. Available online: https://www.ibisworld.com/global/market-research-reports/global-car-automobile-manufacturingindustry/ (accessed on 2 June 2020).

Jeffrey, Joel, and Anthony Putman. 2013. The irrationality illusion: A new paradigm for economics and behavioural economics. Journal of Behavioural Finance 14: 161-94. [CrossRef] 
Johnston, Eric. 2020. Panic-buying of 'made in China' tissues and toilet paper erupts in Japanese cities. Japan Times. Available online: https://www.japantimes.co.jp/news/2020/02/29/national/toilet-paper-tissue-coronavirus/\#. XuXloWozZE4 (accessed on 14 June 2020).

Jones, Katie. 2020. The Pandemic Economy: What Are Shoppers Buying Online during COVID-19? Available online: https://www.visualcapitalist.com/shoppers-buying-online-ecommerce-covid-19/ (accessed on 1 June 2020).

Kaigo, Munego. 2012. Social media usage during disasters and social capital: Twitter and the Great East Japan earthquake. Keio Communication Review 34: 19-35.

Kameda, Tatsuya, and Reid Hastie. 2015. Herd behaviour. In Emerging Trends in the Social and Behavioural Sciences. Hoboken: John Wiley \& Sons.

Keane, Michael, and Timothy Neal. 2020. Consumer panic in the COVID-19 pandemic. ARC Centre of Excellence in Population Ageing Research \& University of New South Wales. CEPAR Working Paper 12: 1-34.

Kennett-Hensel, Pamela, Julie Sneath, and Russell Lacey. 2012. Liminality and consumption in the aftermath of a natural disaster. The Journal of Consumer Marketing 29: 52-63. [CrossRef]

Kilgo, Danielle K., Joseph Yoo, and Thomas J. Johnson. 2019. Spreading Ebola panic: newspaper and social media coverage of the 2014 Ebola health crisis. Health Communication 34: 811-17. [CrossRef]

Knaus, Christopher. 2020. More than 130 Australian companies ready to boost PPE stock of coronavirus masks, gowns and gloves. The Guardian, March 23. Available online: https://www.theguardian.com/world/2020/mar/23/morethan-100-australian-companies-ready-to-boost-ppe-stock-of-coronavirus-masks-gowns-and-gloves (accessed on 3 June 2020).

Kulemeka, Owen. 2010. US consumers and disaster: Observing "panic buying" during the winter storm and hurricane seasons. Advances in Consumer Research 37: 837-38.

Le Grand, Chip. 2020. 'Carpetbaggers and Snake Oil Sellers' Hike Prices on COVID-19 Essentials. Available online: https://www.smh.com.au/national/carpetbaggers-and-snake-oil-sellers-hike-prices-on-covid-19essentials-20200526-p54wgc.html (accessed on 5 June 2020).

Lester, David. 2013. Measuring Maslow's hierarchy of needs. Psychological Reports: Mental E Physical Health 113: 15-17.

Li, Guangdi, and Erik De Clercq. 2020. Therapeutic options for the 2019 novel coronavirus (2019-nCoV). Nature Reviews Drug Discovery 19: 149-50. [CrossRef] [PubMed]

Liu, Wei, Xiao-Guang Yue, and Paul B. Tchounwou. 2020. Response to the COVID-19 Epidemic: The Chinese Experience and Implications for Other Countries. International Journal of Environmental Research and Public Health 17: 2304. [CrossRef] [PubMed]

Loewenstein, George F., Elke U. Weber, Christopher K. Hsee, and Ned Welch. 2001. Risk as feelings. Psychological Bulletin 127: 267-86. [CrossRef]

Mannix, Liam. 2020. The Perfect Virus: Two Gene Tweaks That Turned COVID-19 into a Killer. Sydney Morning Herald. Available online: https://www.smh.com.au/national/the-perfect-virus-two-gene-tweaks-that-turnedcovid-19-into-a-killer-20200327-p54elo.html (accessed on 8 June 2020).

Maslow, Abraham. 1954. Motivation and Personality. New York: Harper and Row Publishers Inc.

Mathes, Brittany, Mary Oglesby, Nicole Short, Amberly Portero, Amanda Raines, and Norman Schmidt. 2017. An examination of the role of intolerance of distress and uncertainty in hoarding symptoms. Comprehensive Psychiatry 72: 121-29. [CrossRef]

McCombs, Maxwell. 2018. Influencing public opinion. In Setting the Agenda: Mass media and Public Opinion. Edited by Maxwell McCombs. Hoboken: Wiley, pp. 1-13.

McKeever, Amy. 2020. Coronavirus is Spreading Panic. Here's the Science behind Why. Washington: National Geographic. Available online: https://www.nationalgeographic.com/history/reference/modern-history/whywe-evolved-to-feel-panic-anxiety/ (accessed on 8 June 2020).

McLeod, Saul A. 2007. Maslow's hierarchy of needs. Simply Psychology. Available online: http://www. simplypsychology.org/maslow.html (accessed on 28 July 2020).

McQuail, Denis. 1977. The influence and effects of mass media. In Mass Communication and Society. London: Edward Arnold, pp. 70-94.

Murphy, Katharine. 2020. Unemployment rate in Australia jumps to 6.2\% due to Covid-19 as 600,000 jobs lost. The Guardian, May 14. Available online: https://www.theguardian.com/business/2020/may/14/unemploymentrate-in-australia-jumps-to-62-due-to-covid-19-as-600000-jobs-lost (accessed on 14 June 2020). 
Myer, Robert, Jay Baker, Kenneth Broad, Jeff Czajkowski, and Ben Orlove. 2014. The dynamics of hurricane risk perception: real-time evidence from the 2012 Atlantic hurricane season: Surveys of coastal residents conducted in 2012 as hurricanes were approaching reveal widespread misunderstanding of the extent and nature of threats posed by tropical cyclones. Bulletin of the American Meteorological Society 95: 1389-404.

Natividad, Ivan. 2020. COVID-19 and the media: The role of journalism in a global pandemic. Berkeley, May 6.

NC Solutions. 2020a. Top Categories on March 12. Available online: https://www.ncsolutions.com/covid/top-cpgcategories-on-march-12/ (accessed on 14 June 2020).

NC Solutions. 2020b. "A Bulk Buying Tipping Point." In NCS COVID-19 Resources. Available online: https://www.ncsolutions.com/covid/a-bulk-buying-tipping-point/ (accessed on 14 June 2020).

NC Solutions. 2020c. COVID-19 Shopping Stages. Available online: https://www.ncsolutions.com/covid/covid-19shopping-stages/ (accessed on 14 June 2020).

Norman, Freya. 2020. Australia tops coronavirus consumer panic. UNSW News Room. Available online: https://newsroom.unsw.edu.au/news/business-law/australia-tops-coronavirus-consumer-panic (accessed on 16 June 2020).

Parse.ly. 2020. Coronavirus Viewership. New York: Parse.ly.

Pieri, Elisa. 2018. Media framing and the threat of global pandemics: the Ebola crisis in UK media and policy response. Sociological Research Online 24: 73-92. [CrossRef]

Rapoport, Anatol, and Albert Chammah. 1965. Sex differences in factors contributing to the level of cooperation in the prisoner's dilemma game. Journal of Personality and Social Psychology 2: 831-38. [CrossRef]

Raymond, Adam K. 2020. Due to coronavirus, these products are suddenly impossible to find. NY Magazine. Available online: https:/nymag.com/intelligencer/2020/05/coronavirus-made-these-products-impossible-tofind.html (accessed on 5 June 2020).

Reid, Leia. 2020. Coronavirus: Looking Back at How Panic Buying Went Viral. Brighton: Brandwatch, Available online: https://www.brandwatch.com/blog/react-coronavirus-panic-buying/ (accessed on 8 June 2020).

Russell, Cally. 2020. What retail categories are booming due to coronavirus? Available online: https://www.forbes.com/ sites/callyrussell/2020/04/15/what-retail-categories-are-booming-due-to-coronavirus/\#7963c0c42e93 (accessed on 12 June 2020).

Samli, Coskun. 2012. International Consumer Behaviour in the 21st Century: Impact on Marketing Strategy Development. New York: Springer.

Siddiqui, Huma. 2020. Fight against COVID-19: All Hands on Board! Rajnath Singh Urges all Organizations to Assist Civilian Authorities. Available online: https://www.financialexpress.com/defence/fight-againstcovid-19-all-hands-on-board-rajnath-singh-urges-all-organizations-to-assist-civilian-authorities/1916134/ (accessed on 16 June 2020).

Slovic, Paul, Melissa L. Finucane, Ellen Peters, and Donald G. Macgregor. 2004. Risk as analysis and risk as feelings: Some thoughts about affect, reason, risk, and rationality. Risk Analysis 24: 311-22. [CrossRef]

Smiedt, David. 2020. 5 Aussie Booze Companies Who Are Now Making Hand Sanitiser. GQ. Available online: https://www.gq.com.au/lifestyle/food-wine/5-aussie-booze-companies-who-are-now-making-handsanitiser/image-gallery/7d958fd349291385449319d0c48f6ec1 (accessed on 1 June 2020).

Smith, Erica. 2020. Behold: The LVMH hand sanitizer. The Cut. Available online: https://www.thecut.com/2020/03/ lvmh-hand-sanitizer-dior-soap-bottle.html (accessed on 1 June 2020).

Swain, Sarah. 2020. Coronavirus: Woolworths and Coles' strict new shopping limits as PM calls to stop panic buying. 9News. Available online: https://www.9news.com.au/national/coronavirus-woolworths-colesshopping-hour/83669f0d-664d-47a8-bc72-963c94a93e42 (accessed on 5 June 2020).

Thomas, Jeff. A. 2014. Community resilience, latent resources and resource scarcity after an earthquake: Is society really three meals away from anarchy? Natural Hazards 74: 477-90. [CrossRef]

Timbrell, Adelaide, and David Plank. 2020. Aus Retail: Stockpiling Peaks. BlueNotes. Available online: https://bluenotes.anz.com/posts/2020/04/anz-research-coronavirus-australian-retail-spend (accessed on 13 June 2020).

Trading Economics. 2020a. U.S. Retail Sales 1992-2020 Data. Available online: https://radingeconomics.com/ united-states/retail-sales (accessed on 14 June 2020).

Trading Economics. 2020b. United States-Advance Retail Sales: Grocery Stores. Available online: https://tradingeconomics.com/united-states/advance-retail-sales-grocery-stores-fed-data.html (accessed on 14 June 2020). 
United Nations. 2014. Ebola Disruption could Spark New Food Crisis. United Nations. Available online: https://www.un.org/africarenewal/magazine/december-2014/ebola-disruption-could-spark-newfood-crisis (accessed on 9 June 2020).

Vitorovich, Lilly. 2020. The Australian online readership doubles during coronavirus. The Australian, April 14. World Health Organisation (WHO). 2020. WHO Coronavirus Disease (COVID-19) Dashboard. Geneva: WHO.

Wray, Meaghan. 2020. Hand sanitiser hoarder under investigation after trying to sell bottles for $\$ 70$ each. Global News. Available online: https:/globalnews.ca/news/6683642/hand-sanitizer-hoarder-coronavirus/ (accessed on 5 June 2020).

Wright, Shane. 2020. Consumer confidence falls to lowest level since last recession. Sydney Morning Herald. Available online: https://www.smh.com.au/politics/federal/consumer-confidence-falls-to-lowest-level-sincelast-recession-20200324-p54d9a.html (accessed on 10 June 2020).

Yang, Jingyu, Yi Li, Wei Liu, and Liang Wen. 2019. Does fdi presence make domestic firms greener in an emerging economy? The effect of media attention. Academy of Management Proceedings 1: 16388-92. [CrossRef]

Yoon, Jiho, Ram Narasimhan, and Myung K. Kim. 2017. Retailer's sourcing strategy under consumer stockpiling in anticipation of supply disruptions. International Journal of Production Research 56: 3615-35. [CrossRef]

Yuen, Kum F., Xueqin Wang, Fei Ma, and Kevin X. Li. 2020. The psychological causes of panic buying following a health crisis. International Journal of Environmental Research and Public Health 17: 3513. [CrossRef]

Zhang, Xaoling, Shibo Li, Raymond R. Burke, and Alex Leykin. 2014. An examination of social influence on Shopper behaviour using video tracking data. Journal of Marketing 78: 24-41. [CrossRef]

(C) 2020 by the authors. Licensee MDPI, Basel, Switzerland. This article is an open access article distributed under the terms and conditions of the Creative Commons Attribution (CC BY) license (http://creativecommons.org/licenses/by/4.0/). 